\title{
The perceived usefulness of the Internet to high school learners in Makhuduthamaga Local Municipality, Limpopo province, South Africa
}

\begin{tabular}{|c|c|}
\hline \multicolumn{2}{|c|}{$\begin{array}{l}\text { Authors: } \\
\text { Mpubane E. Matlala }{ }^{1} \text { (1) } \\
\text { Siyanda E. Kheswa }{ }^{1}\end{array}$} \\
\hline \multicolumn{2}{|c|}{$\begin{array}{l}\text { Affiliations: } \\
\text { 'Department of Information } \\
\text { Studies, University of } \\
\text { KwaZulu-Natal, } \\
\text { Pietermaritzburg, } \\
\text { South Africa }\end{array}$} \\
\hline \multicolumn{2}{|c|}{$\begin{array}{l}\text { Corresponding author: } \\
\text { Mpubane Matlala, } \\
\text { matlalaemanuel@gmail.com }\end{array}$} \\
\hline \multicolumn{2}{|c|}{$\begin{array}{l}\text { Dates: } \\
\text { Received: } 05 \text { Apr. } 2019 \\
\text { Accepted: } 25 \text { Sept. } 2019 \\
\text { Published: } 02 \text { Dec. } 2019\end{array}$} \\
\hline \multicolumn{2}{|c|}{$\begin{array}{l}\text { How to cite this article: } \\
\text { Matlala, M.E. \& Kheswa, S.E. } \\
\text { 2019, 'The perceived } \\
\text { usefulness of the Internet } \\
\text { to high school learners in } \\
\text { Makhuduthamaga Local } \\
\text { Municipality, Limpopo } \\
\text { province, South Africa', } \\
\text { South African Journal of } \\
\text { Information Management } \\
21(1) \text {, a1098. https://doi. } \\
\text { org/10.4102/sajim. } \\
\text { v21i1.1098 }\end{array}$} \\
\hline \multicolumn{2}{|c|}{$\begin{array}{l}\text { Copyright: } \\
\text { (C) 2019. The Authors. } \\
\text { Licensee: AOSIS. This w } \\
\text { is licensed under the } \\
\text { Creative Commons } \\
\text { Attribution License. }\end{array}$} \\
\hline \multicolumn{2}{|l|}{ Read online: } \\
\hline 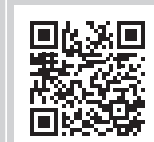 & $\begin{array}{l}\text { Scan this QR } \\
\text { code with your } \\
\text { smart phone or } \\
\text { mobile device } \\
\text { to read online. }\end{array}$ \\
\hline
\end{tabular}

Background: The growth in Internet use has dramatically altered the lives of millions of people around the globe, and it plays a fundamental role in meeting the information and communication needs of learners. The usage of the Internet is a crucial tool for educational progression. Learners use the Internet for various purposes such as social, entertainment and educational activities.

Objectives: To investigate the perceived usefulness of the extent of Internet use by Grade 11 learners from selected high schools within Makhuduthamaga Municipality in Limpopo province.

Method: A quantitative research method was used, with 264 learners participating in the study. Data were collected through questionnaire surveys. A total of 264 questionnaires were send to the participants and all of them were returned, yielding a 100\% response rate, and the data were analysed descriptively.

Results: The findings indicated that the Internet was used for various activities $-78.0 \%$ (205) using it for learning purposes, $46.5 \%$ for communicating with family and friends, $41.0 \%$ to update their knowledge, $18.0 \%$ for entertainment and $11.0 \%$ for news. The findings shed light on the most effective use of the Internet by high school learners, and this implies that schools and policy-makers need to formulate proper ways in which learners can utilise the Internet for their educational activities.

Conclusion: The use of the Internet for teaching and learning purposes demonstrated that it has a strong impact on the quality and accessibility of education and academic performance. This study is significant for high schools and policy-makers in understanding the link between the use of the Internet and its usefulness in learners' education, owing to the fundamental nature of the Internet in the educational environment.

Keywords: Internet use; ICTs; high school learners; learning outcomes; Makhuduthamaga Local Municipality.

\section{Introduction}

It is an undeniable fact that currently we are living in the digital information age, in which utilising the Internet is perceived as the key catalyst for learning environments. This is the result of the development of Information and Communication Technologies (ICTs), which brought about a revolutionary change in service and information provision in schools and education. Idowu and Awodele (2010:30) note that ICT is an umbrella term, which includes the utilisation of computers, smart-phones and the Internet.

Ntombovuyo (2006) asserts that ICT has the potential to meet and support the educational needs of the learners by offering additional study materials and promoting independent learning amongst them. Education has been acknowledged and recognised as an important factor in the public sector, which is mostly influenced by the advancement of ICT tools (Kozma 2005). The educational sectors and schools would reap enormous benefits of ICTs, such as that the ICTs are able to support and enhance learning. Through the Internet, learners can go the extra mile in searching for information and acquiring new knowledge that will supplement what is found in the textbooks and taught in the classrooms (OECD 2016:68).

Consequently, many people perceived the usefulness of the ICTs, as it plays an active role in providing new teaching stimuli and, most critically, provides a viable source of information for 
effective learning. The perceived notion is that ICT tools will produce lifelong learners who will participate in the information society and adapt to the technological era. The role that the perceived usefulness of ICT plays in education has been examined by Eze, Adu and Ruramayi (2013) who noted that the use of the Internet provides opportunities for learners to learn from each other, to collaborate on school assignments, to have clarity when needed by posing questions and have a sense of autonomy. Moreover, the Internet provides learners with valuable information that can be fitted into their learning objectives, thereby enhancing skills development.

The Internet is known as a worldwide system of computer networks that are linked to one another such that the users can access information. Ukpebor and Emwanta (2012) indicated that the influence of the Internet lies in allowing the global community that comprises hundreds of millions of people to communicate, share and exchange information. Yebowaah (2018) argues that the effective use of the Internet signifies the paramount collection of human knowledge and gives the users a great awareness of the global world. It, therefore, provides an opportunity to engage in a variety of thoughts, ideas and philosophies.

In the current technological setting, recent indicators show that the learners are frequent users of the Internet, using it to communicate, search pertinent information, as well as for other important platforms of their choice (Siraj et al. 2015). Ellore, Niranjan and Brown (2014) conducted a study on the influence of Internet use and discovered that most learners can access the Internet via their cell-phones. Therefore, the Internet is useful in helping learners expand their academic and scholarly knowledge (Siraj et al. 2015).

Mashhor and Saad (2014:10) aver that the 'Internet provides tremendous educational benefits including access to information across a wide variety of topics, establishing educational links and enhancing communication with teachers and classmates' and thereby facilitates an inquirybased learning. In high school environments, the Internet is used as a cognitive tool by learners to participate in meaningful and evocative learning (Jonassen 2000). In support, Devi and Roy (2012) noted that the Internet is a multipurpose tool, with a great variety of potential efficacies. It enables learners to communicate with other learners from different places, and exchanges ideas, thoughts and opinions.

This study is based on high schools that are resourceconstrained in Makhuduthamaga Local Municipality, Sekhukhune District, Limpopo province. Makhuduthamaga Local Municipality is known to be one of the poorest and the most compromised municipalities in the province (Hoffman \& Ashwell 2001). The municipality is found within the Sekhukhune District, which 'has been identified as a nodal point for rural development and social transformation' (Rootman, Stevens \& Mollel 2015:96). 'Due to its rural and mountainous nature, it makes the provision and maintenance of services very costly and is confronted with high service delivery backlogs' (Pholotho \& Mtsweni 2016). All of the high schools in the study fall within Quintile 1 (the schools that fall under the classification category of no fee paying).

In terms of ICT infrastructure, the majority of the schools depend largely on 'Very Small Aperture Terminal (VSAT) satellite or Internet, Global System for Mobile Communications (GSM) and Cellular network technologies for data services' (Pholotho \& Mtsweni 2016).

\section{Statement of the problem}

Kobayashi, Ikeda and Miyata (2006:585) states that the Internet holds the greatest potential for learners to develop profound knowledge and execute reflective thoughts within particular tasks. Furthermore, it provides possibilities to complement learners' learning styles and multiple intelligences. In spite of apprehensions, there is much evidence to suggest that the education sector cannot ignore how the Internet has shaped the changes in the society.

Yusuf (2005) notes that high school education has been transformed by the use of Internet, especially in teaching and learning. The Internet has the capability to supplement, strengthen and to reinforce the educational space (Simond 2008). According to South Africa Digitally 2019 Stats, 31.18 million people are active Internet users and 28.99 million people use Internet through mobile phones. 'South Africans spend an average of 8 hours and 32 minutes on the Internet daily' (South Africa Digital Statistics 2019).

The researchers contend that the use of the Internet in schools will prove a more rewarding experience for academic success. The use of the Internet enhances learning, as well as overcomes the challenges or hindrances with regard to improving the effectiveness of both teaching and learning in high schools (Mdlongwa 2012). The use of the Internet increases access to various forms of information and additional pedagogy resources that are not available in the impoverished schools (Pholotho \& Mtsweni 2016).

There is not much literature on the selected high school learners' usage of the Internet in Makhuduthamaga Municipality, despite the fact that anecdotally it is providing a significant opportunity for learning and teaching. This research concerns what learners use the Internet for, and what Internet information services are relevant to them. Leon and Rotunda (2007) claim that the frequent use of the Internet, particularly amongst learners, has also become a highly controversial issue. This means that there is no consensus regarding what exactly the Internet is used for amongst the targeted group of people. This was seen as a challenge, probably owing to the limited amount of work done on the subject. 
The low usage of the Internet in rural high schools impacts negatively on the learners (Koopman 2014):

More often the textbooks that are available are outdated and old and have little relevance to the learners in wildly diverse contexts, therefore learners in the rural schools often miss out. (p. 3)

Padayachee (2017:38) notes that the studies conducted indicate that few high schools in South Africa have incorporated and integrated ICT tools in their pedagogy. According to Peter (2010:10), the objectives for the intake of ICT tools in education comprises social, economic, vocational and pedagogic activities. Furthermore, Peter (2010:10) asserts that the contribution of ICT tools to pedagogy makes 'an improvement of the quality of education by providing rich, exciting and motivation to new learning environments'. With the general issue highlighted, this article examines the perceived usefulness of the Internet amongst high school learners in Makhuduthamaga Municipality, with an emphasis on what they use the Internet for.

\section{Objective of the study}

The key objective of the study was to investigate the perceived usefulness of the extent of Internet use by Grade 11 learners from selected high schools within Makhuduthamaga Municipality, Limpopo province.

\section{Research questions}

1. On which devices do learners access the Internet?

2. What do learners use the Internet for?

3. How often do learners use the Internet?

4. What are the Internet sources or services that learners use the most?

\section{Literature review}

The ICT tools play a vital role in modern society. The positive use of the Internet in learning has been reported by different scholars (Peter 2010; Wheeler 2000), who noted that the Internet encapsulates 'shared learning resources, shared learning spaces, the promotion of collaborative learning and the move towards autonomous learning'. The sharing of resources ensures the positive impacts of improving the quality and minimising the cost associated with learning, in particular under-resourced schools. Wheeler (2002:2) asserts that the use of the Internet creates an active learning environment whereby the school learners can communicate with one another, access a variety of information resources and exchange school-related work.

The Department of Education (DOE) in South Africa recognises the positive impact of ICT in education and supports the introduction and use of the ICT tools in the schooling environment (Department of Basic Education [DBE] 2016:3). The school learners must be able to access, examine, evaluate, incorporate and exchange information with the use of ICT resources in a networked society (DOE
2007:3). The Department of Basic Education (DBE 2016) also corroborates on the criticality of the ICT tools in the transformation agenda of education, particularly to the South African society in general. Subsequently, the South African Department of Basic Education stated that the use of ICT resources should no longer be restricted to the fortunate, it should be available to all school learners (DBE 2016).

The use of the Internet enhances the exchange and retrieval of information and results in new forms of pedagogy, besides other benefits (Sife 2013:1). Masrek, Abdul and Johare (2012:129) argue that the use of the Internet has grown tremendously amongst learners at all levels, right from the primary schools to the higher institutions. Studies have shown that the youth regularly use the Internet to source information related to their personal well-being and for academic purposes (Buami 2013:133). However, the use of Internet in education is not meant to substitute the traditional methods of learning, nonetheless, it intends to supplement school materials to improve student learning (Tishkovskaya \& Lancaster 2012).

The use of the Internet in education or schools is not without challenges. Bingimlas (2009:235) avers that the use of ICT tools in pedagogy is a multifaceted process, which may involve a number of problems. In spite of the significance of the ICTs in education, there are also difficulties that might hinder the quality of teaching and learning. This assertion is equally supported by Tamin et al. (2015:2) who argue that 'there is a misconception that by simply putting this technology in the hands of learners, educational access issues will be resolved and educational transformation will occur'.

The challenges facing high schools with the utilisation of the Internet is idiosyncratic to different school environments. In light of these difficulties, the literature reveals that the most common impediments to the potential use of the Internet include lack of skills, poor network connections, negative perception and lack of school support (Korte \& Huising 2007; Msila 2015). These deeper challenges as espoused by Tamin et al. (2015) appear to focus 'more on the technical aspects rather than the pedagogical and theoretical frameworks'.

In addition, the Internet provides the necessary support for learners in scenarios that involve effective learning by incorporating a variety of learning aids (Jorge et al. 2003). Technological tools do not act as replacement resources for teaching and learning but are assumed to be add-on complements needed for pedagogical purposes. The need of using Internet in education is vital because the pedagogy is not only happening in the school environment but also goes beyond and takes place in a distant environment. Alexandra (2008:37) states that ICT tools have created a paradigm shift in pedagogical practice from direct education and teachercentred classrooms, where most learners rely solely on their teachers for knowledge acquisition, to online learning. The Internet helps learners to become more independent, as they learn to take more responsibility for their own learning. 
Devi (2013:139) avers that in the current scenario the Internet is a highly prevalent and popular technological tool mostly utilised by learners for a variety of purposes, including creating an active setting for exchanging information on an array of diverse subjects. A formal study was carried out by Shiweda (2013) on 'the web-based information behaviour of high school learners in Oshana region, Namibia'. The study revealed that a majority of learners are using the Internet $(86.25 \%)$, where $13.75 \%$ do not use the Internet owing to lack of access. In the same study, it was revealed that most learners use the Internet in their daily routines; $74.60 \%$ used the Internet for seeking information while $58.60 \%$ used it for social networking. This study points to the significance and importance of such technological tools.

Sarfo and Gyimah (2011:221) carried out a study on 'Ghanaian senior high school learners' access to and experiences in the use of information and communication technology'. The results showed that the learners have been using mobile phones and personal computers to access the Internet, and that most of them owned cell-phones. The overall findings indicated that the learners hardly used ICT tools in their schools. It was noted that most of the teachers were digital immigrants, who would not make any attempt to familiarise learners with the Internet in the classrooms. One challenge that hindered learners' use of Internet at schools was their reported inability to use their mobile phones appropriately and pedagogically. This is the main reason as to why they were discouraged from the use of mobile phones at school.

Amenyedzi, Lartey and Dzomeku (2011) echoed similar sentiments in their study, which focussed on assessing Internet usage amongst learners as a supplement to their educational material, in enhancing the standard of education in Ghana. Their study found that learners were using the Internet exceptionally well, in spite of challenges, such as a lack of adequate number of computers and other ICT equipment systems, poor Internet connectivity and a lack of proper ICT policy framework.

In South Africa, Mayayise (2008) conducted a study on the social impact of the Internet using a sample of 50 learners from two high schools in the Gauteng province. The results indicated that there were both positive and negative social impacts of Internet use on these learners. For example, a negative impact was that some learners revealed their personal information to people they met online during chat room sessions. A positive social impact of the Internet was that it created an environment where learners sought information that was needed for educational purposes. Based on the assertions made by the above-mentioned author, it is evident that Internet use has positive benefits that improve learning.

\section{Research methodology}

This study used a quantitative survey design. According to Bryan and Bell (2011:153), a quantitative approach uses a systematic process in which numerical data and measurements are utilised to obtain information on the phenomenon under study. The quantitative research approach attempts to provide the precise nature of a phenomenon, and it largely answers the questions related to how much, how often, how many, when and who (Cooper \& Schindler 2008:165).

For this reason, the total population of this study included the registered Grade 11 learners from seven selected schools in Makhuduthamaga Municipality, Sekhukhune District, which comprises 825 learners in total. It was not feasible to survey the entire targeted population; therefore, the sample that represents the whole population was selected. Based on the large number of learners in the present study, it was concluded that there was a need for sampling (Table 1).

The use of a sample was convenient to administer, and it was found to be 'economical' in terms of cost and time (Majumdar 2005:16). A random sampling technique was consequently employed for obtaining a representative sample from the schools. The sample size was determined by using the sample table by Krejcie and Mogan (1970). This table is applicable to any population of a defined size. According to the Krejcie and Morgan table, a population of 825 has an acceptable sample size of 264 participants.

The data were therefore obtained through questionnaires that were sent to the participants in the study. The participants were required to respond to a variety of questions. The questions were either closed-ended (restricted to given choices) or open-ended (unrestricted to given choices) (Saunders, Lewis \& Thornhill 2009:360). Of the 264 questionnaires that were distributed, all were returned, giving a $100 \%$ response rate.

The choice of techniques and approaches to data analysis was channelled by the nature of the data that were collected. The study collected quantitative data. The analysis of the data was done with the help of the statistical software SPSS ${ }^{\odot}$, Version 22. This software programme was selected because it is a user-friendly data management tool (Migiro 2005:172). All closed-ended questionnaires were first coded in the SPSS database. The analysis process ensured that all the completed questionnaires were initially numbered chronologically; they were then scrutinised to detect any possible errors or omissions in order to ensure maximum data quality (Gichohi 2016:167).

TABLE 1: Population and sample size of the learners.

\begin{tabular}{lccc}
\hline High schools & Population & Sample size & $\mathbf{\%}$ \\
\hline Legare High School & 164 & 53 & 20.0 \\
Masemola High School & 100 & 32 & 12.0 \\
Rantobeng High School & 150 & 48 & 18.0 \\
Bopedi Bapedi High School & 153 & 49 & 18.5 \\
Rebone High School & 129 & 41 & 15.5 \\
Ngwanamatlang High School & 25 & 8 & 3.5 \\
Ngwabe High School & 104 & 33 & 12.5 \\
\hline Total & $\mathbf{8 2 5}$ & $\mathbf{2 6 4}$ & $\mathbf{1 0 0}$ \\
\hline
\end{tabular}

Source: Matlala, M.E., 2015, 'The use of the Internet by grade 11 learners from selected high schools in the Sekhukhune District, Makhuduthamaga Local Municipality in Limpopo Province', p. 49, Master's thesis, University of KwaZulu-Natal, Pietermaritzburg. 
The quantitative data collected were analysed using inferential statistics and descriptive statistics, in which the means, percentages and frequencies were conceded out to satisfy the objectives of the study, make estimates, draw interpretations and enable recommendations (Gichohi 2016:167).

\section{Results and findings}

The participants were asked to specify their electronic device of choice for Internet access. Table 2 shows that the most frequently used facilities to access the Internet were the smart-phone (87\%), tablet (17\%) and laptop (14\%). The leastused facility was the desktop computer, with only $11 \%$ of the respondents indicating their usage of this facility.

The participants were asked about their purpose of using the Internet. The results in Table 3 indicate that a sizeable number, 205 participants $(78.0 \%)$, utilised the Internet for learning purposes. This was followed by 123 (46.5\%) respondents who used it for communicating with family and friends, and 107 respondents $(41.0 \%)$ who used it to update their knowledge. The smallest number of respondents, a total of 29 $(11.0 \%)$, indicated that they used it for the news updates, while 48 (18.0\%) respondents used it for entertainment.

In order to assess the frequency of Internet usage, the participants were asked to specify any one of the four time categories given in Table 4. The frequency of use amongst the respondents ranged from daily use, to never used the Internet. The researchers gauged the purpose of Internet use of the learners through the following question: How often do learners access the Internet for academic purposes in a week? Regarding frequency of Internet use by the respondents, 264 learners, and 135 (51\%) respondents, indicated that they used the Internet daily.

This could be interpreted as a consequence of the majority of the respondents having access to smart-phones. They were followed by $95(36.0 \%)$ respondents who used the Internet once a week and $22(8.3 \%)$ respondents who used the Internet once a month. Eleven (4.2\%) respondents used the Internet once every 2 weeks, and only one $(0.4 \%)$ never used the Internet (see Table 4).

Table 5 gives an overview of the Internet sources or services learners use. A total of 216 (82\%), the largest number of respondents, used the search engine Google, 151 (57\%) used social networks and $25(9 \%)$ respondents used the email facility. Followed by 13 (5\%), the lowest number of respondents, used the Microsoft network.

\section{Discussion}

In investigating the perceived usefulness of the Internet use by high school learners, numerous questions were raised. The assigned respondents were asked about the electronic devices they used to access the Internet. Table 2 shows that the most frequently used facilities to access the Internet were
TABLE 2: Learners accessing the Internet.

\begin{tabular}{lcc}
\hline Method & Frequency & $\mathbf{\%}$ \\
\hline Smart-phone & 226 & 87 \\
Tablet & 46 & 17 \\
Laptop & 37 & 14 \\
Desktop computer & 28 & 11 \\
\hline Total & $\mathbf{3 3 7}$ & $\mathbf{1 2 9}$ \\
\hline
\end{tabular}

Source: Matlala, M.E., 2015, 'The use of the Internet by grade 11 learners from selected high schools in the Sekhukhune District, Makhuduthamaga Local Municipality in Limpopo Province', p. 59, Master's thesis, University of KwaZulu-Natal, Pietermaritzburg.

TABLE 3: The purpose of learners' Internet use: Multiple responses.

\begin{tabular}{lcc}
\hline Purpose & Frequency & $\mathbf{\%}$ \\
\hline For learning purposes & 205 & 78.0 \\
To communicate with family and friends & 123 & 46.5 \\
To update knowledge & 107 & 41.0 \\
For entertainment & 48 & 18.0 \\
For the news & 29 & 11.0 \\
\hline Total & $\mathbf{5 1 2}$ & $\mathbf{1 9 4 . 5}$ \\
\hline
\end{tabular}

Source: Matlala, M.E., 2015, 'The use of the Internet by grade 11 learners from selected high schools in the Sekhukhune District, Makhuduthamaga Local Municipality in Limpopo Province', p. 65, Master's thesis, University of KwaZulu-Natal, Pietermaritzburg.

TABLE 4: Frequency of using the Internet.

\begin{tabular}{lcc}
\hline Frequency of use & Frequency & $\mathbf{\%}$ \\
\hline Daily & 135 & 51.0 \\
Once a week & 95 & 36.0 \\
Once a month & 22 & 8.3 \\
Once every 2 weeks & 11 & 4.2 \\
Never used the Internet & 1 & 0.4 \\
\hline Total & $\mathbf{2 6 4}$ & $\mathbf{1 0 0}$ \\
\hline
\end{tabular}

Source: Matlala, M.E., 2015, 'The use of the Internet by grade 11 learners from selected high schools in the Sekhukhune District, Makhuduthamaga Local Municipality in Limpopo Province', p. 66, Master's thesis, University of KwaZulu-Natal, Pietermaritzburg.

TABLE 5: Internet sources or services that learners use the most.

\begin{tabular}{lcc}
\hline Services & Frequency & $\mathbf{\%}$ \\
\hline Google & 216 & 82 \\
Social networks & 151 & 57 \\
E-mail & 25 & 9 \\
Microsoft network & 13 & 5 \\
\hline Total & $\mathbf{4 0 5}$ & $\mathbf{1 5 3}$ \\
\hline
\end{tabular}

Source: Matlala, M.E., 2015, 'The use of the Internet by grade 11 learners from selected high schools in the Sekhukhune District, Makhuduthamaga Local Municipality in Limpopo Province', p. 64, Master's thesis, University of KwaZulu-Natal, Pietermaritzburg.

the smart-phone (87\%), the tablet (17\%) and the laptop (14\%). The least-used facility was the desktop computer (11\%). The current findings are in agreement with the findings of the research conducted by Shiweda (2013:83) on 'the web-based information behaviour of high school learners in Oshana region, Namibia', where it was discovered that 114 (82.6\%), a majority of learners, used cell-phones to access the Internet.

The findings of the current study are similar to those of Shiweda (2013), who found that many learners, 105 (76.1\%), access the Internet at home. Poscia et al. (2015:129) said that the use of cell-phones is one of the most rapidly growing technologies in the world, with more than 6 billion subscribers, as reported by the United Nations.

Aoki and Downes (2003:362) also noted that, 'cell phones are a pervasive new communication technology', most specifically used amongst the youth. The cell-phones that have access to the Internet are more common in the current 
setting. The use of the Internet through cell-phones has allowed young people to surf the Internet and is gaining attention. Aboderin et al. (2011) reported that $65 \%$ of the learners are accessing the Internet for academic purposes. This implies that the use of the cell-phones contribute greatly to the learners accessing the Internet. Cell-phones have been frequently used for learning purposes in most countries, including South Africa. Kruger (2010:6) states that one of the benefits of cell-phones is, unlike computers, that it allows users to accomplish any activity while not being required to stay in one place.

The results in Table 3 indicated that 205 (78.0\%), the majority of the participants, used the Internet for learning purposes; this was followed by $123(46.5 \%)$ of the respondents indicating that they used it for communicating with family and friends, while $107(41.0 \%)$ used it to update their knowledge. The smallest number of respondents, a total of $29(11.0 \%)$, indicated that they used it for news updates, while $48(18.0 \%)$ respondents used it for entertainment. The findings of Table 3 are in agreement with that of Kanlaya (2013:252), which showed that the respondents used the Internet in their everyday life because they appreciated its speed, the variety of information it offers access to and the ease of access to information. Also, the respondents were of the opinion that the information obtained on the Internet is more accurate and up to date than that found in most books.

Devi and Roy (2012:184) attested to the fact that most people and high school learners use the Internet and other technological tools for learning. It is clear that the Internet plays a key role in modern life. It has recently been reported that the youth of 'today spend a significant amount of their time on the Internet, using it for multiple purposes' (Bragdon \& Dowler 2016; Ogedebe 2012).

When it comes to the frequency of using the Internet services, Table 4 reveals that amongst the 264 learners that responded, 135 (51\%) used the Internet daily, 95 (36\%) used the Internet once a week, $22(8.3 \%)$ used the Internet once a month, $11(4.2 \%)$ used the Internet once every 2 weeks and $1(0.4 \%)$ never used the Internet. These results agree with a study conducted by Emeka and Nyeche (2016) on the impact of Internet use for academic purposes by learners in Abuja, Nigeria. The findings indicated that:

$111(55 \%)$ of the participants used the Internet daily; 31 (15\%) used it once a week; $9(5 \%)$ used it once in 2 weeks; $26(13 \%)$ used it once in a month; 20 (10\%) used it occasionally; while $3(2 \%)$ do not use Internet at all. (Emeka \& Nyeche 2016:1025)

Bragdon and Dowler (2016) argued that college students spend most of their time using the Internet for educational and work-related activities; most of them spent $42.8 \mathrm{~h}$ per week accessing the Internet. Olatokun (2008) has indicated that a 'large proportion of high school learners in Nigeria have been using the Internet in their everyday lives for about 4 to 5 years now'. Kumar and Kaur (2006) stated that $48.3 \%$ students in Punjab, Haryana and Himachal Pradesh use the
Internet 2-3 times a week; $40 \%$ utilise the Internet daily; and $6.0 \%$ use it $2-3$ times a month. These results also indicated that majority of the participants $(69.4 \%)$ use the Internet for educational activities, $41.0 \%$ for updating knowledge, $47.4 \%$ for communication, and $35.0 \%$ for entertainment.

Table 5 was examined for an overview of the Internet service providers used by the learners. The results showed that 216 $(82.0 \%)$ of the respondents used the search engine Google; 151 (57.0\%) used the social networks; $25(9.0 \%)$ of the respondents used only the email; and $13(5.0 \%)$ respondents used the Microsoft network. This is in line with the findings of Islam and Hossain (2012:7), who found that the respondents used the Internet mainly for social networking. It was revealed that $44.7 \%$ of the respondents used the Internet for Facebook; $43.7 \%$ used it for email; $35.8 \%$ used the Internet for conducting school work; and $25.3 \%$ used the Internet for both browsing websites and downloading other information; $20.5 \%$ used the Internet for entertainment; and $18.4 \%$ used the Internet for chatting.

As an overall trend, it is clear that the respondents have different reasons for using the Internet, depending on their need. For example, it is not surprising to see them using the Internet for academic purposes, while at the same time using it for other purposes, such as socialising; consequently, the use of Facebook has become a top priority of the respondents.

\section{Conclusion and recommendations}

The rationale of this study was to investigate the perceived benefits of Internet use to high school learners in Makhuduthamaga Local Municipality, Limpopo province. It was pertinent for this study to be conducted in order to determine the benefits of Internet use to learners, the frequency of Internet use amongst high school learners and the most used sources or services.

The study reveals that Internet use has a significant influence and plays a very critical role in the academic activities of high school learners. The use of the Internet has impacted educational practices in a positive manner. It cannot be denied that the Internet use has great benefits for the learning processes, quality and accessibility of education, which in turn increases performance.

Therefore, the acceptance and the use of the Internet in the educational environment have a good influence on pedagogy, as it enables wider access and enhance the sharing of vital general and school-related information between the learners through the use of cell-phones. Moreover, the Internet is very useful in the current networked society wherein technological tools are frequently utilised. This study drew on the experiential results of various high schools.

The research findings of the current study are of significance to the researchers and school policy-makers. This study is significant for high schools and policy-makers in understanding the link between the use of the Internet and 
its usefulness in learners' education, owing to the fundamental nature and importance of the Internet in the educational environment. A significant approach is to recommend a possible alignment of ICT tools and pedagogical activities that will ensure that the learners embrace and utilise the technological tools in their learning activities. The positive contribution of using the Internet in schools is that it will increase flexibility of accessing information and also enable learners to access information, regardless of time and geographical barriers. It is recommended that:

- The mainstreaming of the use of the Internet in education enhances learners' quality of education. Consequently, policy-makers and all the stakeholders involved in the education fraternity ought to recognise the potential benefits of ICT tools in education towards the efficient functioning of the technology in the educational setting.

- The school teachers must give learners assignments that will compel them to utilise the Internet in their scholarly work.

- The school management need to embark on awareness programmes that will sensitise the school learners to take advantage of using the Internet for school activities.

- Government ought to give support to the high schools with ICT tools that will have access to the Internet services. This would equip the learners with the Internet skills necessary for success in an information society.

\section{Acknowledgements}

The authors are grateful to the participants for their time and effort in materialising this study.

\section{Competing interests}

The authors declare that they have no financial or personal relationships that may have inappropriately influenced them in writing this article.

\section{Authors' contributions}

M.E.M. devised the topic for the Master's Research thesis and S.E.K. helped in refining it in his capacity as the supervisor. M.E.M. drafted the article out of the Master's study and sent it to S.K. for review and positioning. M.E.M. and S.E.K. contributed to the design and implementation of the research, to the analysis of the results and to the writing of the manuscript.

\section{Ethical consideration}

The researchers were guided by, and adhered to, the ethical code of the University of KwaZulu-Natal. The code is concerned with questions of anonymity, privacy and confidentiality of the learners. In addition to this, the researchers obtained informed consent from the Department of Education in Limpopo Province and also from the principals. All participants were clearly informed of the research objectives, and their consent in writing was obtained prior to participation.

\section{Funding information}

No financial support was accrued for this article and it was conducted for academic purposes and adding new information to the identified problem.

\section{Data availability statement}

Any data that support the findings of this study are included within the article.

\section{Disclaimer}

The views expressed in this article are that of the authors and not necessarily the position of the University of KwaZulu-Natal.

\section{References}

Aboderin, O.S., Fadare, O.G., Kumuyi, G.J., Lawal, O.O. \& Babtunde, O.H., 2011 'Pedagogical appraisal of Internet and computer usage among secondary school teachers and students in South Western part of Nigeria', World Journal of Young Researchers 1(4), 54-59.

Alexandra, P.J., 2008, 'Leadership behaviour and technology activities: The relationship between principals and technology use in schools', PhD thesis, University of Central Florida, Orlando, FL.

Amenyedzi, F.W.K., Lartey, M.N. \& Dzomeku, B.M., 2011, 'The use of computers and Internet as supplementary source of educational material: A case study of the senior high schools in the Tema Metropolis in Ghana', Contemporary Educationa Technology 2(2), 151-162.

Aoki, K. \& Downes, E.J., 2003, 'An analysis of young people's use of and attitudes toward cell phones', Telematics and Informatics 20(1), 349-364. https://doi. org/10.1016/S0736-5853(03)00018-2

Bingimlas, K.A., 2009, 'Barriers to the successful integration of ICT in teaching and learning environments: A review of the literature', Eurasia Journal of Mathematics, Science and Technology Education 5(3), 235-245. https://doi.org/10.12973/ ejmste/75275

Bragdon, R.A. \& Dowler, K., 2016, 'College student technology use and academic performance. Center for Promoting Ideas, USA', International Journal of Humanities and Social Science 6(1), 12-22.

Bryan, A. \& Bell, E., 2011, Business research methods, 3rd edn., Oxford University Press, London.

Buami, E.K., 2013, 'Internet using habit among Junior High School students of Nima Accra-Ghana', International Journal of ICT and Management 1(3), 133-138.

Cooper, D.R. \& Schindler, P.S., 2008, Business research methods, 10th edn., McGrawHill, Boston, MA.

Department of Basic Education (DBE), 2016, Information quide for 17th annual NTA 2016, Department of Basic Education, Pretoria, viewed 20 December 2018, from http://www.education.gov.za/LinkClick.aspx?fileticket=FbCMTbqRPMo\%3D\&tabi $\mathrm{d}=441$ \&portalid $=0 \&$ mid $=3091$.

Department of Education (DOE), 2007, Education change and transformation in South Africa: A review. 1994-2001, Department of Education, Pretoria.

Devi, C.B. 2013, 'Internet surfing among the students of Assam University, Silchar', International Journal of Research in Computer Application and Management 3(6), 139-147.

Devi, C.B. \& Roy, N.R., 2012, 'Internet use among university students: A case study of Assam University Silchar', A Journal of Humanities and Social Science 1(2), 183-202.

Ellore, S.B., Niranjan, S. \& Brown, U.J., 2014, 'The influence of Internet usage on academic performance and face-to-face communication', Journal of Psychology and Behavioural Science 2(2), 163-186.

Emeka, U.J. \& Nyeche, O.S., 2016, 'Impact of Internet use on the academic performance of undergraduates students: A case study of the University of Abuja, Nigeria' International Journal of Scientific and Engineering Research 7(10), 1018-1029.

Eze, R.I., Adu, E.O. \& Ruramayi, T., 2013, 'The teachers and the use of ICT for professional development in Botswana', International Journal of Economy, Management and Social Sciences 2(2), 26-30.

Gichohi, P.M., 2016, 'The role of public libraries in the development of small-scale business enterprises in Meru County, Kenya', PhD thesis, University of South Africa, Pretoria.

Hoffman, T. \& Ashwell, A., 2001, Nature divided: Land degradation in South Africa, University of Cape Town Press, Cape Town.

Idowu, S. \& Awodele, O., 2010, 'Information and Communication. Technology (ICT) revolution: Its environmental impact and sustainable development', International Journal of Computer Science and Engineering 2(1), 30-35.

Islam, A. \& Hossain, M.J., 2012, 'Access and use of the Internet among undergraduate students in the Faculty of Arts, University of Dhaka, Bangladesh', Pakistan Journal of Library and Information Science 13(2), 1-20. 
Jonassen, D.H., 2000, Computers as mind tools for schools: Engaging critical thinking 2nd edn., Prentice-Hall Inc., Upper Saddle River, NJ.

Jorge, C.M.H., Gutierrez, E.R., Garcia, E.G., Jorge, M.C.A. \& Diaz, M.B., 2003, ‘Use of the ICTs and the perception of e-learning among university students: A differential perspective according to gender and degree year group', Interactive Educational Multimedia $7(3), 13-28$.

Kanlaya, D., 2013, 'The effect of the Internet use on high school students: A case study of Pattani Province of Thailand', Procedia Social and Behavioural Sciences 91(10), 241-256. https://doi.org/10.1016/j.sbspro.2013.08.422

Koopman, M., 2014, Step by step approach: The integration of ICT in the classroom in rural African schools, viewed 31 July 2019 from https://ieeexplore.ieee.org/ stamp/stamp.jsp?tp=\&arnumber $=7058144$

Korte, W.B. \& Husing, T., 2007, 'Benchmarking access and use of ICT in European schools 2006: Results from head teacher and a classroom teacher surveys in 27 European countries, eLearning papers' 2, 1: 1-6, viewed 18 July 2019, from www. elearningeuropa.info/files/media/media11563.pdf.

Kobayashi, T., Ikeda, K. \& Miyata, K., 2006, 'Social capital online: Collective use of the Internet and reciprocity as lubricants of democracy', Information, Community and Society 9(5), 582-611.

Kozma, R.B., 2005, 'National policies that connect ICT-based education reform to economic and social development', An Interdisciplinary Journal on Humans in ICT Environments 1(2), 117-156. https://doi.org/10.17011/ht/urn.2005355

Krejcie, R.V. \& Morgan, D.W., 1970, 'Determining sample size for research activities', Educational and Psychological Measurement 30(10), 607-610.

Kruger, J., 2010, Latest ICT trends in enhancing education, Department of Informatics, University of Pretoria, Pretoria, viewed 20 December 2019, from http://web. up.ac.za/ecis/sacla2010pr/sacla2010/papers/sacla029.pdf.

Kumar, R. \& Kaur, A., 2006, 'Internet use by teachers and students in engineering colleges of Punjab, Haryana, and Himachal Pradesh states of India: An analysis', Electronic Journal of Academic and Special Librarianship 7(1), 30-43.

Leon, D.T. \& Rotunda, R.J., 2007, 'Contrasting case studies of frequent Internet use: Is it pathological or adaptive?', Journal of College Student Psychotherapy 14(4), 9-18. https://doi.org/10.1300/J035v14n04_03

Majumdar, P.K., 2005, Research methods in social science, Viva Books Private Limited, New Delhi.

Mashhor, A. \& Saad, A., 2014, 'Internet addiction among secondary school students in Riyadh city, its prevalence, correlates and relation to depression: A questionnaire survey' International Journal of Medical Science and Public Health 3(1), 10-15. survey', International Journal of Medical Science
https://doi.org/10.5455/ijmsph.2013.130920131

Masrek, M.N., Abdul, N.S. \& Johare, R., 2012, 'The relationship between Internet attitude and Internet addiction', Asian Journal of Information Technology 11(4) 125-130. https://doi.org/10.3923/ajit.2012.125.130

Matlala, M.E., 2015, 'The use of the Internet by grade 11 learners from selected high schools in the Sekhukhune District, Makhuduthamaga Local Municipality in Limpopo Province', Master's thesis, University of KwaZulu-Natal, Pietermaritzburg.

Mayayise, T.O., 2008, 'The social impact of the Internet on Gauteng high schoo learners', Master's thesis, University of Pretoria, Pretoria.

Mdlongwa, T., 2012, Information and communication technology as a means of enhancing education in schools in South Africa: Challenges, benefits and recommendations, Africa Institute of South Africa (AISA), Pretoria.

Migiro, S., 2005, 'Small and medium-scale manufacturing enterprises in Kenya: A perspective on alternative sources of financing', Master's thesis, University of Zululand, KwaDlangezwa.

Msila, V., 2015, 'Teacher readiness and information communications technology (ICT) use in classrooms: A South African case study', Creative Education 6(18) (ICT) use in classrooms: A South African case study',

Ntombovuyo, K., 2006, 'An investigation of the effective use of information and communication technologies (ICT) for primary school teachers in the transfer of knowledge', Master's thesis, University of Stellenbosch, Stellenbosch.

Ogedebe, P.M., 2012, 'Internet usage and students' academic performance in Nigeria tertiary institutions: A case study of University of Maiduguri', Academic Research International 2(3), 334-343.
Olatokun, W.M., 2008, 'Internet access and usage by secondary school students in a Nigerian Municipality', South African Journal of Libraries and Information Science 74(2), 138-148. https://doi.org/10.7553/74-2-1295

Organization for Economic Co-operation and Development (OECD), 2016, Innovating Education and Educating for Innovation: The power of digital technologies and skills, viewed 20 December 2018 from http://www.oecd.org/education/ceri/ GEIS2016-Background-document.pdf.

Padayachee, K., 2017, 'A snapshot survey of ICT integration in South African schools', South African Computer Journal 29(2), 36-65. https://doi.org/10.18489/sacj.v29i2.463

Peter, C.P., 2010, A guide to academic writing, Zapf Chancery, Eldoret.

Pholotho, T. \& Mtsweni, J., 2016, 'Barriers to electronic access and delivery of educational information in resource constrained public schools: A case of Greate Tubatse Municipality', IST-Africa Conference Proceedings, viewed 20 July 2019 from https://researchspace.csir.co.za/dspace/bitstream/handle/10204/9340/ Pholotho_18155_2016.pdf?sequence=1\&isAllowed=y.

Poscia, A., Frisicale, E.M., Parente, P., La-Milia, D.I., De-Waure, C. \& di-Petro, M.L., 2015, 'Study habits and technology use in Italian University students', Annali dell'Istituto Superiore di Sanità 51(2), 126-130.

Rootman, G.T., Stevens, J.B. \& Mollel, N.M., 2015, 'Policy opportunities to enhance the role of smallholder livestock systems in Limpopo Province of South Africa', South African Journal of Agricultural Extension 43(2), 91-104.

Sarfo, F.K. \& Gyimah, A.K., 2011, 'Ghanaian senior high school students' access to and experiences in the use of information and communication technology', Turkish Online Journal of Educational Technology 9(4), 216-223.

Saunders, M., Lewis, P. \& Thornhill, A., 2009, Research methods for business students, 5 th edn., Prentice Hall Financial Times, Harlow.

Shiweda, T.P., 2013, 'Web-based information behavior of high school learners in Oshana region, Namibia', Master's thesis, University of KwaZulu-Natal, Pietermaritzburg.

Sife, A.S., 2013, 'Web search behaviour of postgraduate students at Sokoine University of Agriculture, Tanzania', Library Philosophy and Practice 897(Winter), 1-16, viewed 19 Decembre 2018, from https://digitalcommons.unl.edu/libphilprac/897.

Simond, M., 2008, Influence of Internet on the education system, viewed 12 August 2017, from http://ezinearticles.com/?Influence-of-Internet-on-the-EducationSystem\&id=985543.

Siraj, H.H., Salam, A., Hasan, N.A., Jin, T.H., Roslan, R.B. \& Othman, M.N.B., 2015, Internet usage and academic performance: A study in a Malaysian Public University. Japan Health Sciences University and Japan International Cultural University. Japan Health Sciences University and Japan Internation

South Africa Digital Statistics, 2019, Where is South Africa digitally in 2019: The stats, viewed 20 March 2019, from https://flickerleap.com/south-africa-digitally-2019-stats/.

Tamin, R., Borokhovski, E., Pickup, D. \& Bernard, R., 2015, Large-scale, governmentsupported educational tablet initiatives, Commonwealth of Learning, Burnaby.

Tishkovskaya, S. \& Lancaster, G.A., 2012, 'Statistical Education in the 21st Century: A review of challenges, teaching innovations and strategies for reform', Journal of Statistics Education 20(2), 1-24.

Ukpebor, O.C. \& Emwanta, M.G., 2012, 'Availability and the use of computer and Internet by secondary school students in Benin City, Nigeria', International Journal of Library and Information Science 4(2), 16-23. https://doi.org/10.5897/ IJLIS11.027

Wheeler, S., 2000, 'The role of the teacher in the use of ICT', Keynote Speech Delivered to the National Czech Teachers' Conference, University of Western Bohemia Czech Republic, Learning Technology Research, viewed 20 July 2019, from https:// www.oerafrica.org/FTPFolder/guyana/CCTI\%20CD/CCTI\%20CD/ukzncore1b/ documents/core1b.role_teacher_ict.htm.

Yebowaah, F.A.Y., 2018, 'Internet use and its effect on senior high school students in Wa Municipality of Ghana', Library Philosophy and Practice, 1-30, viewed 20 December 2018, from https://digitalcommons.unl.edu/cgi/viewcontent.cgi?artic le=5094\&context=libphilprac.

Yusuf, M.O., 2005, 'Information and communication education: Analyzing the Nigerian national policy for information technology', International Educational Journal $6(3), 316-321$ 